\title{
EVALUATING THE SCHOOL TEXTBOOKS FROM THE PERSPECTIVE OF STUDENTS
}

\author{
Rahmayani ${ }^{1}$, Anwar $^{2}$, Amzah Selle ${ }^{3}$ \\ Institut Agama Islam Negeri (IAIN) Parepare ${ }^{123}$ \\ rahmayaniahmad@gmail.com ${ }^{1}$
}

\begin{abstract}
This research examined about the students' need on the textbook and whether it is fulfilled their needs. The purpose was to find out the textbook acceptablity by analyzing the students' needs on their textbook according to the students opinion on it. This research used triangulation method such as interview, questionnaire, and observation. The primary data was taken from the interview, while the questionnaire and observation used as supporter or secondary data. The reseacher used wants analysis to find the students' need. The questions of the interview and questionnaire were designed and developed according to the evaluation domains. As the findings showed that the textbooks that are used in several senior high school in Parepare can be considered acceptable.
\end{abstract}

Keywords: Textbook, Evaluation 


\section{Introduction}

Evaluation in education has always been done since it is considered as a crucial thing that has certain role in our education life. Every education activity is something that always been proceed according to the applied standard. Because, in the principle, education is an activity where the process and target achievement are measurable. That is why, an appropriate evaluation system is needed. Among the teaching-and learning aspects that should be evaluated is the textbook used by teacher in schools. Teachinglearning activity, especially in the classroom, cannot be separated from some aspects that support its goals. One of the supporter aspects is the instructional material. Instructional materials are the tools used in educational lessons, which includes active learning and assessment (Anynomous, 2016). Basically, the resource that teacher used in teaching is the instructional material. Instructional material has many types, but one that becomes the most common known in education is traditional resource which includes any textbooks used in the classroom.

The role of textbook in education has not been questioned. It contains materials of learning and teaching that is needed by both teacher and students. Among its functions are; textbook is framework which organized and scheduled the teaching program activity; student has considered textbook as the part of teaching-learning activity which sometimes be meant "no textbook no material"; in any situation, textbook may play role as syllabus; textbook provides teaching instruction and already prepared assignments; and the last, textbook is the easiest way to prepare learning material (Mudzakkir, 2003). According to these functions, it can be concluded that the role of textbook is very important in our educational system.

Textbook, however, is an instructional material that always needs to be developed and evaluated to upgrade the quality. The efforts for this matter have been done by some either experts or researchers in many ways. In the curriculum development, an evaluation is done in every stage of curriculum development, starting from need analysis, objectives, testing, material, and teaching.

Masyhudi latif in his research entitle An Evaluation of English Textbook for the Eight Graders of Junior High School, in 2015 has conducted a textbook evaluation which focus on analyzing the textbook appropriateness through content analysis according to experts criteria. 
The newest issue that is relevant to the textbook evaluation in Indonesia is the revision of 2013 curriculum which has been announced in the early of 2016 by the Ministry of Education. The changing of 2006 curriculum to 2013 curriculum also affects the education paradigm that is moving from teacher centered to student centered. For this reason, the role of textbook as a learning resource is absolutely important. Because, it is undeniable that the students will grapple a lot to their textbook beside to teacher.

By looking at what the mentioned researchers have done, it can be concluded that the researchers generally evaluated the textbook only on either textbook coverage or content analysis, textbook curriculum fitness, and any textbook evaluation effort that is mostly relating to the given standard without pay more attention to the students' attitude and needs on their textbook. There is actually no harm on it, but then, the main users of the textbook are students and teacher. So, to encompass more complete information of good textbook, it is very important to engage the students in revealing their needs on the textbook.

Based on the above explanations, the writer proposes two research questions; the students' perception to the English textbook used for Senior High School in Parepare, and whether the English textbook used for Senior High School students in Parepare fulfill the needs of learners. According to the background stated in the beginning, this reseach has several objectives; examining the acceptability of the textbook by evaluating the textbooks according to the students' needs, engaging students in evaluating the textbook so that the upcoming textbook writer will be aware on what the students really need to be delivered on their textbook, giving comments to the prevailing curriculum for the better quality, as well as giving recomendation for the government as the determiner of national textbook.

\section{Method}

As the type of this study used qualitative research where this kind of study is designed to obtain current phenomenon, the researcher uses descriptive qualitative as the research design. This research is also designed to inqure about the Senior Highs School students' perception in Parepare about their textbook. 
This research was conducted in several Senior high Schools in Parepare. The Schools were selected in the consideration that they are using the textbook proposed by the governement (2013 Curriculum). Based on this criteria, the researcer has selected SMA Negeri 1 Parepare, SMA Negeri 2 Parepare, SMA Negeri 5 Parepare, and Man 2 Parepare as the chosen schools for conducting this research. This study took arround one to two weeks .

This research focused on some stated questions; the students perception and expectation of the textbook in language learning, and how the textbook fulfill the needs of students regarding to the language use and textbook content. Students are engaging in this study because they can provide written or oral feedback or comments on the materials used which relevance to the students' needs (Richard). To give a clear limitation of study, the researcher emphasize that the using of standarized criteria that are proposed by experts or government are not used here. The reason is that this study is not focus on content analysis such the previous researcher, Masyhudi Latif, has done by highlighting on some aspects on his evaluation. This is because the researcher believes that those aspects or focus have already been evaluated by the textbook evaluator in this case is ministry of Education via BSNP, and evaluating textbook from government is not the capabilty of the researcher as an undergraduate students.

The kinds of data that was collected in this research include as primary data which was taken from some schools in Parepare as the population targets. The data was collected by using random sampling. The samples are from each selected schools (SMA Negeri 1 Parepare, SMA Negeri 2 Parepare, SMA Negeri 5 Parepare, and Man 2 Parepare). The quantification for amount of samples are divided in two parts. The first, data for questionnaire engage thirty students, data for interview are five.

A questionnaire contains a set of questions or written statements to be responsed or ansewered by a big number of respondent. The type questionnaire that is used here is rating scale. There are arround twenty questions or statements to be answered by students. Next, interview is used to obtain more detail explanation of the data and there was arround eight questions to be answeres as well. The designed questions or statements for survey questionnaire and interview are inherited from some proposed criteria (evaluation domains). As for the observation, was done by observing the situation in the classroom and the school library. As this research used qualitative, so 
the procedure for data collection may be happened naturally. The students were given a set of statements or questions where they need to give a checklist to the statements that they may agree or disagree with it. In the interview, the researcher select the students randomly and interview them according to the evaluation domains that have been elaborated in several questions.

As this study use descriptive research, so that the data was delivered in several form of presentation. The data from questionnaire, interview, and observation were analyzed descriptively by making the transcription and interpretation of the them inductively with some domains as the focus. The researcher proposed some criteria which is needed to be evaluated. These domains are adapted from some experts criteria such as Bryd, Riddell, as well as celce murcia, and several previous researchers own constructed criteria. Here, the researcher developed her own domains for some consideration. Firstly, the researcher only selected the necessary criteria proposed by the experts and previous researcher which fit the condition of textbook using in Indonesia. It is well known that since the changing of 2006 curriculum to 2013 curriculum, most school in Indonesia use textbook proposed by the goverment. The textbook, however, has attained through several stages or process including experts review, re-checked, etc., before officially released to school. Secondly, the selected domain may enable the students in evaluating the textbook according to their capability, and to ease the researcher in analysing the students' review.

Table 1. Evaluation domains composed by researcher

\begin{tabular}{|c|c|c|}
\hline Evaluation Domains & Interview & Questionnaire \\
\hline \multicolumn{3}{|l|}{ Students intensity in using textbook } \\
\hline \multicolumn{3}{|l|}{$\begin{array}{l}\text { Students dependency to the textbook during the } \\
\text { learning process }\end{array}$} \\
\hline \multicolumn{3}{|l|}{ Language use of the textbook } \\
\hline \multicolumn{3}{|l|}{ Exercises and homework } \\
\hline \multicolumn{3}{|l|}{ Presentation (cover, texts, pictures, tables,etc.) } \\
\hline \multicolumn{3}{|l|}{ Theme and topics in context } \\
\hline \multicolumn{3}{|l|}{ Linguistic aspects (grammar,vocabularies, phonology) } \\
\hline Language skills (listening, reading, writing, speaking) & & \\
\hline
\end{tabular}




\section{Results}

As the last stage of the research, finding becomes the most awaited and crusial part. Before this section, the researcher first of all reduced the data from the interviews and observation or the quantitative data survey questionaire (self reflection sheet). The datas from interview were reduced by omitting the unnecessary information from the recording. The recoding then displayed in the form of transcription. After that, the trancriptions were analyzed by domain analysis. In addition, the researcher also used a quantitative data to get a more comprehensive opinion of the students which in this case used survey questionnaire by using self-reflection sheet with closed-ended questions. The datas from this quantitive way were presented in the form of persentage. The followings are the findings of this research.

In the students intensity in using textbook, Some students use textbook in the classroom. The textbooks are provided by school to support the learning process. The textbooks are used during the learning process e.g. in doing excercises or assigments (material instruction). It also help the teacher when the teacher cannot attend the class. In the other hand, some students also seldom or unfrequently use the textbook in the classroom because the teacher prefer to give lecturing method or use technology such as LCD projector, internet, printed materials, or anther learning resources in the learning process. Even so, the students are still given textbook to be used at school and at home.

In contrary, some the students who do not use textbook at home think that they are not merely given homework relating to textbook. The existence of internet nowadays also make students to rely on technology where they can download many resources by one click. Moreover, the the quota of the textbook itself is still unable to let every person of student get the book. For all that, there are still some students admit that they still use textbook at home. The factor is that they are sometimes given homework by teacher relating to textbook. By these facts, it is known that most students are intensively interact with the textbook eventhought the using of the textbook is not as often as the past time.

Students dependency to the textbook during the learning process is rated low. As the fact shows, internet has become not only as secondary resources, but also as main reference. As it function as material instruction, textbook is totally adressed for assigments or homework. Textbook does not cover all material that students may need. 
It mostly contain with excercises and homework. By this reason, students are encouraged to always look for references to support the textbook.

As for the language use of the textbook, The first aspect to be commented in language use here is the using of target and source language. Some students prefer that the textbook should be in full English, but not a few of them feel more comfortable if the textbook also use bahasa Indonesia or their source language (bilingual). For those who choose the textbook delievered in full English state that it is more challenging and encourage the students to be more independent (not rely on the translation). Other reasons are students will be stimulated to use the target language which it invites curiousity as well as accustoming the students with English. In the other hand, not a few students agree with that. Some who prefer bilingual state that full English textbook do not make them feel at ease when learning. The problem of limited vocabulary, become one of the most dominant reasons which always appear. Moreover, the problem of misinterpretation of target language which can lead them to misunderstanding may become a serious problem for the students by remembering that not all of them have the same proficiency in English. Again, not all teacher allow the students to use smartphone during learning process.

The second aspect for language use is students' opinion of the presented dialogues in the textbook. Some students think that the words or expression available in the textbook are standard (not too difficult or easy). It because the selected words in textbook are classified as common words. The dialogues for their level are quite perceiveable. So sometimes they even do need to look for the meaning on dictionary. The dilagues in students' opinion are easy to understand and interesting and able to broaden their mind. Nevertheless, several students find them difficulty, specially for complicated words.

The third item of language use is students' dependency to teacher when it deals to the barriers in facing the textbook. Lack of vocabulary, misinterpretation of complicated words, and in need of further explanation of the instruction on the excercises and homeworks are some barriers that students face deal with the textbook.

The domain of exercises and homework deals with the level of complexity of instructions in excercises and homework. Some students argue that the provided excercises and homework are fair or easy enough, although a few students fail to 
understand the questions because lack of vocabulary. Further explanations by teacher are needed to avoid misunderstanding of the excercise's instruction because not all questions on textbook are clear and easy to understand. For some students, the level of excercises difficulty is not too high. While the amount of task for the students are too much. They believe that textbook actually should prepare more examples than excercises.

In the aspectPresentation (cover, texts, pictures,etc.), There are various opinion of the textbook cover from the students. Some said that it is enough interesting because it show the symbol of nations, the colour is blue which represent neutral colour, exposing unique color, interesting but less picture, providing picture but meaningless.

On the contarary, some who disagree that the cover is interesting think that the colour combination is too bleak. Cover shall at least provide a motivating slogan. Meanwhile, there are also students think that the cover is just ordinary or moderate. As for them, It shows something very usual eventhought the book was editied with a full colour.

The next item for presentation is the lenght of the text. Most students argue that the text provided on thir textbook are not too long and complicated. But even so, there are also some students who find it that long and complicated because they have low prociency in in English and lack of grammar. The student, however, suggest not to put long text on their textbook because it will not be effective and attractive if the texts are too long.

The last items for presentation are picture and tables. The existence of picture in the textbook is one important aspect that should not be skipped. The availability of enough pictures in the textbook made the students feel satisfy because it will not lead them to the boredom and increase the students' ability to analyze the task. It also becomes one that attracts students to read. Most of the interviewed students stated that they are more comfortable if the textbook provide more pictures than texts, as long as the pictures relate to the material. Other students argue that even thought the textbook has provided the enough pictures, but they found them monotonous because they are not sufficient colorful. In the other hand, another student responded the portion of pictures and texts has been balance. For the tables, some students say that their textbook provided tables but they never find any graphic or chart in it. 
For most students, they agree that the theme and topics presented in the textbooks are interesting. It because the themes are strongly related to their daily life. There are several favorite themes or topics proposed by the students. For example environment, telling about their self, something relates to teenager, or even religion. In the other side, some students do not think that the themes and topics are just ordinary or even not interesting. They believe the themes and topics are something very common and always repeated since in junior high school.

In linguistic aspects (grammar,vocabularies, phonology,etc) and language skills (listening, reading, writing, speaking), Grammar, in this item, is the main point to be evaluated. The students' textbook, however, has provided the grammar either in the form of pattern or implicitly shown in the reading texts or stories. Most of the students state that their textbooks have provided the grammar e.g. tenses, personal pronoun, and so on. But most of them said that the grammar is not clear or detail enough. It made them confuse when facing the patterns while they do not have any knowledge of grammar and the way to use them. Although some also think that the detail explanation of the grammar will come from the teacher, but most of them expect the textbook may describe them the grammar use at least.

The next crucial item is vocabulary. The existence of vocabulary and its components are important. According to the students, their textbooks only served words list with their description in target language and did not provide any translation. For certain textbook such proposed textbook by the government, it still provided vocabulary builder and glossary for students. But the other textbooks did not provided vocabulary and the components. Although they provide them, the components of vocabulary such as parts of speech, pronunciation, and the translation are sometimes ignored. In students' opinion, they expect that some complicated words can be attached together with the translation or when to use them.

The last item to be evaluated is the language skill. Many students see those fourth skills presented in their textbooks have suited their capability. The aspect of language skill is not very debating among students because most of them agree that their language skills are not very difficult.

Talking about students' satisfaction on textbook, the textbooks provided at school are rated quite unsatisfactory. There are several factors should be taken into 
account because the textbooks still unable to fulfill the needs of the students. There are some aspects which must be considered. The first, the use of source language, detail information of grammar, the presentation (specially in presenting colorful and interesting pictures), providing interesting text with attactive and fresh stories, the texts are not very long, giving a detail explanation for the material including the necessary of the material, providing a lot of practice and giving more realistic examples, mindbroadening materials, contextual, and real-life dialogues, providing quotes from inspiring people where it can awaken the students spirit to learn, providing way to use/apply those materials to the daily life, giving pictures for every dialogues to understand the text, serving a glossary that provide explanation for complicated words to more comprehend the material, as well as the content is taken from the most updated material (the newest issue in the world).In conclusion, the textbook used at school are still unable to meet the need most of students. Even so, a few students find their textbook rather satisfying.

Beside the using of qualitative data, this research is also supported by quantitave data which engaged 108 students with 2160 items. The following are the presentation of the data which was analyzed by using percentage. The data on the table below showed the students' intensity in using textbook at home is rare. Only 47\% students used textbook at home for various reasons. Even so, $57 \%$ use them at school. It indicates that the students are intensively interacting with their textbook.

Table 2. Comments in SMAN 1 Parepare

\begin{tabular}{|c|c|c|c|c|c|c|c|}
\hline \multirow{2}{*}{ Q. NUMBER } & \multicolumn{7}{|c|}{ SMA 1} \\
\hline & YES & NO & ss total & YES percentage & NO percentage & domains & percentage \\
\hline 1 & 17 & 18 & 30 & 56,66666667 & 43,33333333 & \multirow{2}{*}{ ss intensity } & always \\
\hline 2 & 14 & 16. & 30 & 46,66666667 & 53,33333333 & & rare \\
\hline 3 & 14 & IE & 30 & 46,66666667 & 53,33333333 & \multirow{2}{*}{ ss dependency } & not depending \\
\hline 4 & 22 & 1 & 30 & 73,33333333 & 26,66666667 & & not depending \\
\hline 5 & 16 & 24 & 30 & 53,33333333 & 46,65666667 & \multirow{4}{*}{ language use } & Target lang. \\
\hline 5 & 14 & 36 & 30 & 46,666666667 & 53,33333333 & & Target lang. \\
\hline 7 & 22 & 8 & 30 & 73,33333333 & 26,66666667 & & easy \\
\hline 8 & 24 & E & 30 & 80 & 20 & & difficult \\
\hline 9 & 8 & 77 & 30 & 26,66666667 & 73,33333333 & \multirow{2}{*}{ exc. \& hw } & difficult \\
\hline 10 & 20 & 10 & 30 & 66,66666667 & 33,33333333 & & easy \\
\hline 11 & 12 & 28 & 30 & 40 & 60 & \multirow{4}{*}{ p,c, etc. } & easy \& short \\
\hline 12 & 24 & 8 & 30 & 80 & 20 & & interesting: \\
\hline 13 & 22 & 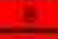 & 30 & 73,33333333 & 26,66666667 & & interesting \\
\hline 14 & 28 & 2 & 30 & 93,33333333 & 6,666666667 & & easy \\
\hline 15 & 27 & 9 & 30 & 90. & 10 & \multirow{2}{*}{ theme/topic } & interesting: \\
\hline 16 & 3 & 28 & 31 & 9,677419355 & 90,32258065 & & interesting \\
\hline 17 & 21 & 8 & 30 & 70 & 30 & \multirow{2}{*}{ L. Aspect } & easy \\
\hline 18 & 25 & 5 & 30 & 83,33333333 & 16,666666667 & & available \\
\hline 19 & 25 & 8 & 30 & 83,33333333 & 16,66666667 & L. Skil I & easy \\
\hline 20 & 15 & 15 & 30 & 50 & 50 & satisfaction & average \\
\hline
\end{tabular}


Next, the students' dependency as shown by the table is rated not depending. It proves that students generally use more than one resource or textbook. For the language use, most students feel more comfortable to use the target language than the source language. Even so, they still rely the most to the teacher in comprehending the textbook. The presentation aspect such as pictures and textbook cover are interesting, and the text length and complexity are sufficient easy. The themes and topic are interesting for the students. Linguistic aspects and language skills are also rated interesting. The satisfaction percentage above showed average number which means the textbook used in Senior High School 1 is rated satisfying for some aspects but do not suit the students in other aspects.

Table 3. Textbook comments in SMAN 2 Parepare

\begin{tabular}{|c|c|c|c|c|c|c|c|}
\hline \multirow{2}{*}{ Q. NUMBER } & \multicolumn{7}{|c|}{ SMA 2} \\
\hline & YES & NO & ss total & YES percentage & NO percentage & domains & percentage \\
\hline 1 & 29 & 1 & 30 & 96,66666667 & 3,333333333 & \multirow{2}{*}{ ss intensity } & ałways \\
\hline 2 & 9 & 21 & 30 & 30 & 70 & & rare \\
\hline 3 & 18 & 17 & 30 & 60 & 40 & \multirow{2}{*}{ ss dependency } & depending \\
\hline 4 & 20 & 6 & 30 & 66,666666667 & 33,33333333 & & not depending \\
\hline 5 & 10 & 30 & 30 & 33,33333333 & 66,66666667 & \multirow{4}{*}{ language use } & Source lang. \\
\hline 6 & 20 & 10 & 30 & 66,666666667 & 33,33333333 & & Source lang. \\
\hline 7 & 21 & 9 & 30 & 70 & 30 & & easy \\
\hline 8 & 28 & 2. & 30 & 93,33333333 & 6,666666667 & & difficult \\
\hline 9 & 11 & 19 & 30 & 36,66666667 & 63,33333333 & \multirow{2}{*}{ exc. \& hw } & difficult \\
\hline 10 & 13 & 17 & 30 & 43,33333333 & 56,66666667 & & difficult \\
\hline 11 & 17. & B & 30 & 56,66666667 & 43,33333333 & \multirow{4}{*}{$p, c$, etc. } & not interesting \\
\hline 12 & 23 & 21 & 30 & 76,666666667 & 23,33333333 & & interesting \\
\hline 13 & 23 & 7 & 30 & 76,666666667 & 23,33333333 & & interesting \\
\hline 14 & 27 & 3 & 30 & 90 & 10 & & easy \\
\hline 15 & 25 & s: & 30 & 83,33333333 & 16,66666667 & \multirow{2}{*}{ theme/topic } & interesting \\
\hline 16 & 5 & 8 & 30 & 16,666666667 & 83,33333333 & & interesting \\
\hline 17 & 21 & 8 & 30 & 70 & 30 & \multirow{2}{*}{ L. Aspect } & easy \\
\hline 18 & 24 & S: & 30 & 80 & 20 & & available \\
\hline 19 & 26 & 4 & 30 & 86,666666667 & 13,33333333 & L. Skil I & easy \\
\hline 20 & 20 & to & 30 & 66,666666667 & 33,33333333 & satisfaction & satisfied \\
\hline
\end{tabular}

The table above the students, intensity in using textbook at home is still rare. But they highly use textbook at school in learning process. The dependency of the students on textbook is also rated high eventhough they still use another textbook to support their main reference. The demand of the students on source language is $67 \%$ which means highly demanded. The language use in the dialogues are quite easy for the students. Nevertheless, they are still depending on the teacher in understanding the instructions or materials in the book.

For the excercises, most of the students think that the excercises and homework provided in their textbook are difficult. They also think that the texts are quite long and 
complicated. The other aspects of presentation are cover and picttures. Most of the students agree if the cover has been interesting for them. The same with the cover, the pictures provided in their textbook are also interesting. Beside of interesting, they are also easy to be understood by the students.

Next, the theme and topics. As for the theme and topics, the students are mostly agree that they are enough interesting. The textbook was also rated easy from the aspects of linguistics and language skill. As the conclusion, the textbook used for the students of Senior High School 2 has been able to fulfill the students's needs.

Table4. Textbook comments in SMAN 5 Parepare

\begin{tabular}{|c|c|c|c|c|c|c|c|}
\hline \multirow{2}{*}{ Q. NUMBER } & \multicolumn{7}{|c|}{$5 M A 5$} \\
\hline & YES & NO & Ss total & YE5 percentage & NO percentage & domains & percentage \\
\hline 1 & 23 & 7 & 30 & 76,66666667 & 23,33333333 & \multirow{2}{*}{ ss intensity } & always \\
\hline 2 & 16 & 12 & 30 & 53,33333333 & 46,666666667 & & always \\
\hline 3 & 8 & 22 & 30 & 26,666666667 & 73,33333333 & \multirow{2}{*}{ ss dependency } & not depending \\
\hline 4 & 29 & 1 & 30 & 96,666666677 & 3,333333333 & & not depending \\
\hline 5 & 13 & 12 & 30 & 43,33333333 & 56,66666667 & \multirow{4}{*}{ language use } & Source lang. \\
\hline 6 & 18 & in? & 30 & 60 & 40. & & Source lang. \\
\hline 7 & 27 & 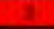 & 30 & 90 & 10 & & easy \\
\hline 8 & 20 & ID. & 30 & 66,666666667 & 33,33393333 & & diffficult \\
\hline 9 & 23 & 2 & 30 & 76,66666667 & 23,33333333 & \multirow{2}{*}{ exce, \& hw } & easy \\
\hline 10 & 10 & 20 & 30 & 33,33333333 & 66,66666667 & & difficult. \\
\hline 11 & 7 & 23 & 30 & 23,33333333 & 76,666666667 & \multirow{4}{*}{ D,c, etc. } & interesting \\
\hline 22 & 26 & 4. & 30 & 86,66666667 & 13,33333333 & & interesting \\
\hline 13 & 23 & 2 & 30 & 76,666666667 & 23,33333333 & & interesting \\
\hline 14 & 29 & 20 & 49 & 59,18367347 & 40,81632653 & & easy \\
\hline 15 & 27 & 1 & 30 & 90 & 10 & \multirow{2}{*}{ theme/topic } & interesting \\
\hline 16 & 3 & 28 & 30 & 10 & 90 & & interesting \\
\hline 17 & 25 & If & 30 & 83,33333333 & 16,66666667 & \multirow{2}{*}{ LAspect } & easy. \\
\hline 18 & 24 & 68 & 30 & 80 & 20 & & available \\
\hline 19 & 23 & 32 & 30 & 76,66666667 & 23,33333333 & L.Skil I & easy \\
\hline 20 & 11 & 18 要 & 30 & 36,66666667 & 63,33333333 & satisfaction & unsatisfied \\
\hline
\end{tabular}

The table above showed the percentange of students' opinion on textbook used in senior high school 5 Parepare. According to the students intensity, they use the textbook very often because the intensively interact with it in either at school or at home. But, they did not depend on the textbook because they use more than one resouce. From the language use aspect, they prefer if their textbook provide them the source language as well. They agree that the dialogues or text in their textbook are easy enough to be understood, but they also still need teacher's help for understanding them. Excercises are rated easy but they need the further explanation from teacher to understnd the instruction.

For the text, it is not too long and complicated for them. The appearance of the textbook by the cover and the picures inside the book are also interesting. It is the same thing with the theme and topics which are rated interesting. From the aspect linguistic 
and language skill are also rated easy for the students. Nevertheless, the students think that the book is not enough satisfiying for them.

Table 5. Textbook comments in MAN 2 Parepare

\begin{tabular}{|c|c|c|c|c|c|c|c|}
\hline \multirow{2}{*}{ Q NUMBER } & \multicolumn{7}{|c|}{ MAN 2} \\
\hline & YES & No & ss total & YES percentage & NO percentage & domains & percentage \\
\hline 1 & 16 & 3 & 18 & 88,88888899 & 11,11111111 & \multirow{2}{*}{ ss intensity } & always \\
\hline 2 & 8 & 10 & 18 & 44,44444444 & 55,55555556 & & rare \\
\hline 3 & 10 & I & 18 & 55,55555556 & 44,44444444 & \multirow{2}{*}{ ss dependency } & depending \\
\hline 4 & 17 & \pm & 18 & 94,44444444 & 5,555555556 & & not depsnding \\
\hline 5 & 3 & 15 & 18 & 16,666666667 & 83,33333333 & \multirow{4}{*}{ language use } & Source lang \\
\hline 5 & 13 & 3 & 18 & 72,222222222 & 27,77777778 & & Source lang \\
\hline 7 & 10 & 8 & 18 & 55,55555556 & 44,44444444 & & easy \\
\hline 8 & 8 & 10 & 18 & 44,44444444 & 55,55555556 & & etasy \\
\hline 9 & 3 & 15 & 18 & 16,66666667 & 83,33333333 & \multirow{2}{*}{ exc, \& hw } & difficult \\
\hline 10 & 4 & If & 18 & 22,22222222 & 77,77777778 & & difficult \\
\hline 11 & 15 & 2 & 18 & 83,33333333 & 16.666666667 & \multirow{4}{*}{$\rho, c$, etc. } & not interesting \\
\hline 12 & 13. & 3 & 18 & 72.222222222 & 27,77777778 & & interesting \\
\hline 13 & 17 & 1 & 18 & 94,44444444 & 5,555555556 & & inturesting \\
\hline 14 & 12 & 勧 & 18 & 66,66666667 & 33,33333333 & & easy \\
\hline 15 & 10 & 6 & 18 & 55,55555556 & 44,44444444 & \multirow{2}{*}{ theme/topic } & interestiny \\
\hline 16 & 8 & 10 & 18 & 44,444444444 & 55.55555556 & & interesting \\
\hline 17 & 12 & 6 & 18 & 66,665666667 & 33,33333333 & \multirow{2}{*}{ L. Aspect } & easy \\
\hline 18 & 16 & 2 & 18 & 88,88688869 & 11,11111111 & & avaliable: \\
\hline 19 & 11 & 3 & 18 & 61,11111111 & 38,88888899 & L.Skil I & easy \\
\hline 20 & 13 & 2 & 18 & 72,222222222 & 27,77777778 & satisfction & satisfied \\
\hline
\end{tabular}

The table above is the percentage of the students' opinion about the English textbook at their school. Students' intensity in using the textbook at school and home is quite different. The using of textbook at school is more often that at home. Their dependency on the textbook is rated high where they take the textbook as their main reference and rarely use additional resouces.

For the language use they agree that the textbook dialogues are easy (eventhough the needs of the source language is high) so they do not rely the most to the teacher. The excercises and homework are rated difficult for them. From the showed data can be seen that in the aspect of presentation, cover and provided pictures become the most attracted aspect for the students, while text is noticed uninteresting because the lenght and complexity.

The theme and topic are interesting. Likewise to the grammar, vocabulary, etc., and the providing of language skill which are rated easy. As the conclusion, the students think that the textbook has satified them from those several aspects.

In the observation, the researcher did not emphasize the research to a very depth observation. The observation was done in the same day of doing the interview. So the researcher unseperated or even sequencing the time in chronological order. There are a some information that the researcher noticed. First, the using of the textbook in the 
classroom as not as rapid as before. The influence of technology and improvement of material instructions are some of the factor. The existence of electronic textbook (ebook) has also changed the learning orientation at school. According to the observation at the school libaray, some school such as Senior high school 5 and MAN 2 Parepare has not provided enough textbook for students. In SMAN 5, Even so, the role of textbook as the teachers guide and students' material instruction is considered important.

\section{Discussion}

This section is going to elaborate the data from the finding above. In the first part, it was explaining about the interpretation of the interview. As it has been proposed in the chapter of methodology, there are eight focused domains; students intensity in using textbook, students dependency to the textbook during the learning process, language use of the textbook, exercises and homework, presentation (cover, texts, pictures,etc.), theme and topic, linguistic aspects (grammar,vocabularies, phonology,etc) and language skills (listening, reading, writing, speaking), as well as students' satisfaction on textbook. From these domains, later, it will be known the students opinion relating to the mentioned domains and whether the textbook fulfill the students' needs of textbook.

As it is seen the students intensity is rated high when it deals with the classroom using. Their dependency which is rated low is seen as a normal thing by remembering the main purpose of textbook is as material instruction. From the language use view, it is analyzed that the needs of students to the exsistence of source language is highly needed. For particular textbook e.g. textbook proposed by government, has provided the vocabulary builder. While the other textbook did not provide them. As material instruction, textbook commonly deals with excercises or assigments. In commenting the textbook, some students argue that the provided excercises and homework are fair or easy enough, although a few students fail to understand the questions because lack of vocabulary.

According to Jack C. Richards some potential problems that may appear on textbook such as containing inauthentic language, distorting content, and not reflecting the students'need. Distorting content means textbook often present an idealized view of 
the world or fail to represent real issue. This statement strongly relate to the students opinion about presenting the updated issue in textbook where it provide a lot of practice and giving more realistic examples, mind-broadening materials, contextual, and real-life dialogues.

Comparing the percentage of each school, we can see the most debating domains need to be discussed are the language use and the excercises. These are taken in the consideration that the domains showed unsatisfying result. In the language aspect., the providing of source language in full English textbook is necessary. Eventhough the selected dialogues provided in textbook was claimed standarized, but the dependy of the students is very high.

In general conclusion, the textbooks that are used in several senior high school can be considered acceptable. Nevertheless, it still need to be improved for fulfilling the needs of the students in some aspects. As the table 0.5 shows, the highlighted aspects such as language use and the excercises or homework can all be taken into account when providing learning material for students.

\section{Conclusion}

In the very first chapter of this research, it is well known that there are two objectives of the research. They are students perception to the English textbook used for Senior High School in Parepare, and the acceptability of the textbook to the students by analyzing the students need (the ability of the textbook in fulfilling the needs of the students).

From the data of interview and questionnaire, it is claimed that the data of interview has answered the first problem statement. The finding has explicitly elaborate what students' actully think about their textbook, what are their opinion to their textbook, and whan they want on their textbook. Similarly to the data from the table. The table 0.5 shows a clear data about which aspect that the students may feel unsatisfy. According to the quantitative data, generally, most of the students feel satisfy with their textbook. There are only some aspects that do not meet their needs. Likewise to the data from interview. Some respondent think that the some aspects have not met their needs. So, from this explanation, the researcher conclude that the textbooks used in Senior High School in Parepare are still acceptable, but not completely fulfill the needs of the 
students. The researcher believes that this research may contain some mistakes in either tehnically the methodology or data analysis, the researcher suggest the next researcher to give more attention to this vey cruicial matter. As researcher realize that this work still far from the perfection, further comments or advices are very welcomed. For the next researchers who are going to do the same topics of research, it is better to limit your research on the certain book only if you want to comments the book in particular. It is hope, the upcoming school textbook will be more acceptable and able to fulfill the needs of students by considering some important datas above.

\section{References}

Anonym, "Instructional materials: Definition,Examples \& Evaluation. (2016). " Online Article. study.com/academy/lesson/instructional-materials-definitionexamples-evaluation.html (September 15th).

Anonym. (2016). "Evaluation Defined," http://www.socialresearchmethods.net/kb/interval.htm (Accessed on September, 6th).

Center for Teaching, Research and Learning. (2017). "Qualitative research" https://www.american.edu/ctrl/upload/Qualitative-Research-Introduction.pdf (Accessed March,24th).

Balachandran, Divya. (2017). "Criteria-Based Post-Use Evaluation of English Textbooks", International Journal of English Language, Literature, and Humanities. http://ijellh.com/papers/2014/September/07-72-88-sept2014.pdf?x72302 (Accessed on March 4th).

Dickins, Pauline Rea- and Kevin Germaine. Evaluation (Oxford: Oxford University Press).

Didi. (2017). "Evaluasi Pembelajaran Bahasa Inggris", http://www.academia.edu/3095487/EVALUASI_PEMBELAJARAN_BAHAS A_INGGRIS (Accessed on May, 24th).

Gak, Dragana M. (2017). "Textbook - An Important Element in The Teaching Process" https://www.coursehero.com/file/19510082/771-1314-1-SM-1pdf/ (Accessed on February, 20th). 
House, Dayna. (2016). "Evaluating Your Textbook", https://www.slideshare.net/EmbajadaEEUUenArgentina/evaluating-yourtextbook (Accessed on August, 31st).

Islam, Md. Monjurul. (2017). “An Evaluation of English Textbook from Teachers' Perspective," International Journal of English Language Education. http://ijee.org/yahoo_site_admin/assets/docs/11.17210659.pdf (Accessed on September, 24th).

Latif, Masyhudi. (2015). “An Evaluation of English Textbook for the Eight Graders of Junior High School “ (Undergraduate Thesis; Faculty of Language and Arts: Yogjakarta).

Lecture notes and summary, "Need Analysis," official website of creative common attribution. Www.scientficlanguage.com/esp/needsanalysis.pdf (February, 20th 2017).

Lenon, Barnaby. 2017 "Textbooks Have a Huge Impact on Eduction", http://www.telegraph.co.uk/education/educationopinion/11739310/Textbookshave-a-huge-impact-on-education.html (Accessed on February, 22nd).

Mudzakkir. 2003. "Penulisan Buku Teks Bahasa Arab" (The Paper presented in Language Teaching National Seminar FPBS UPI: Bandung).

National Center for HIV/AIDS (CDC), “Types of Evaluation" https://www.cdc.gov/std/Program/pupestd/Types\%20of\%20Evaluation.pdf (September, 6th 2017).

Qodriani, Laila Ulsi. (2014). Analisis Buku Sekolah Elektronik Bahasa Inggris SMP/MTs Kurikulum 2013 When The English Rings The Bell, (A Thesis: Faculty of Arts, Yogyakarta).

Richard, Jack C. Curriculum Development in Language Teaching, (Cambridge: Cambridge Press).

Richard, Jack C. (2017). "Evaluating a $\quad$ Textbook," http://www.professorjackrichards.com/wp-content/uploads/role-oftextbooks.pdf (Accessed on May, 16th).

Saepuddin. et. al., eds. (2013). Pedoman Penulisan Karya Ilmiah (Makalah dan Skripsi) Sekolah Tinggi Agama Islam Negeri (STAIN) Parepare Tahun 2013. Parepare: STAIN Parepare. 
Shah, Syed Kazim, Shahista Hassan, and Wajiha Iqbal. (2015). "Evaluation of Textbook as Curriculum: English for 6 and 7 Graders in Pakistan," International Journal of English Language Education. http://dx.doi.org/10.5296/ijele.v3i2.8042 (September 5th).

Shah, Syed Kazim, Shahista Hassan, and Wajiha Iqbal. (2015). "Evaluation of Textbook as Curriculum: English for 6 and 7 Graders in Pakistan,” International Journal of English Language Education. http://dx.doi.org/10.5296/ijele.v3i2.8042 (Accessed on September, 5th).

Sheldon, Leslie E, ed. (1987). ELT Textbook and Materials: Problems in Evaluation and Development (Oxford: The Eastern Press Ltd).

Songhori, Mehdi Haseli. (2017). "Intoduction to Needs Analysis", www.esp-world.info (Accessed on February, 22th).

"Textbooks". (2017). Wikipedia the Free Encyclopedia. www.wikipedia.com (february 28th).

Tyler, Raplh W. (1949). Basic Principles of Curriculum and Instuction, (Chicago: The University of Chicago Press).

Tomlinson, Brian. (1998). Materials development in language teaching (United Kingdom: Cambridge University Press).

UNESCO. (2017). Guidelines for Curriculum and Textbook Development in International Edcation, in the preface of Kaisa Savolainen http://collections.infocollections.org/ukedu/en/d/Js1497b/1.1.html (Accessed on August, 29th).

Yassi, Abd.Hakim and Andi Kaharuddin Bahar. (2015). Syllabus Design for English Language Teaching (Yogyakarta:Trust Media Publishing). 